\title{
Study on Transferring Price Problem of Multinational Corporations
}

\author{
Xiling Dai \\ School of Business Administration, Shenyang University, Shenyang 110044, China \\ E-mail: sydxdxl@163.com
}

\begin{abstract}
With the development of global economic integration trend, multinational corporations have already become the main body of economic activity in the world today, and the transferring price of the multinational corporations have already become the most attractive business secret weapon in the multinational corporations operating. At first, the paper discusses the definition, species and roles of the multinational corporations then analyses the motivation of the multinational corporations using transferring price. At last, the paper proposes the suggestions to consummate management mechanism of transferring price, based on analyzing the harm for the multinational corporations to misuse the transferring price.
\end{abstract}

Keywords: Multinational corporations, Transferring price, Problem

The $21^{\text {st }}$ century is the century of economic globalization. With the development of the economic globalization, the marketing activities of many international enterprises change from the traditional form of import and export trade to the new form of cooperation, joint ventures and franchising and so on. The multinational corporations have developed rapidly since 1970. A number of powerful international corporations have set up subsidiaries or branches overseas. The parent company allocates all kinds of resources all over the world in order to use the resources effectively and improve the overall benefits. Because the parent company and its subsidiaries are all economic entities with dependent accounting at different levels, the corresponding price should be made to the goods and services transferred during the course of the transaction in order to reasonably determine the operation performance of each branch. Therefore, the transferring price in the international market appears. Multinational corporations have great advantages in the aspect of the trade and investment, and their business activities are all over the world, therefore, they become a key driver of economic globalization. As international market competition intensifies, transferring price of multinational corporations has an increasingly important role. Therefore, study on the transferring price problem of multinational corporations becomes an important task.

\section{Introduction to the transferring price problem of multinational corporations}

The transferring price of multinational corporations is the internal price that multinational corporations use to settle the transfer of the goods and intangible assets or services provision between the parent company and subsidiaries, or only between subsidiaries when the multinational corporations make its overall business strategy in order to achieve maximum profits. The transferring price is not affected by the market rules of support and demand. It is not decided by the independent competition principle in the open market, but decided by the top decision-makers in the corporation according to the global strategy objective and the aim to achieve the maximum profits.

The transferring price of multinational corporations can be divided into three kinds: (1) Capital circulation transferring price, which means that in the internal trade, multinational corporations improve the goods price imported from a parent or other subsidiaries in order to make the profit exported by the form of loan payment, then affect the cost of the related company and the profit level by the level of interest rates of borrowing funds. (2) Tangible assets transferring price, which means the allocation price of rental and transfer of tangible assets such as machines and equipments in the multinational corporations. (3) Intangible assets transferring price, which refers to the price that multinational corporations provide intangible assets such as management, technology and consulting service.

Transferring price provides a lawful and effective means for the multinational corporations to overcome trade barriers, reduce the tax burden, reduce transaction risk and improve economic efficiency; and make the multinational corporations achieve a competitive advantage in the market. Therefore, transferring price strategy is the favorable leverage for the multinational corporations to realize the centralized control, unified deployment of human, finance and material all over the world, and also the necessary tool to realize their global strategy.

\section{The motive of multinational corporations to use transferring price strategy}

The multinational corporations may achieve a lot of advantages and benefits by implementing the transferring price strategy, which is the motive of multinational corporations to use transferring price strategy. The motive can be divided into the following three kinds.

\subsection{Evading tax}

The multinational corporations often artificially raise or lower transaction price and transfer the profit from the 
countries with higher tax rates to the countries with lower tax rates so that they can minimize corporate income tax burden by the use of national differences in tax rates, preference of free port, and other relevant laws and regulations about regional customs union. In addition, the multinational corporations still often use lower transaction price between internal enterprises to reduce the base of paying customs, or use regional customs union or the relevant preferential provision in the agreement to evade custom.

\subsection{Dodging risk}

The multinational corporations may face a number of risks in the course of operation, and they often use the transferring price to dodge risk. The first risk is the risk of exchange rate movements. In recent years, the foreign exchange market in the world is volatile, and currency parity in various countries fluctuate very largely and frequently, which makes international enterprises with companies all over the world exposed in the large foreign exchange risk. The multinational corporations not only face the risk of trade transactions, but also face the risk of foreign currency translation of assets. Multinational corporations usually take the opportunity to select the appropriate exchange rate to pay, and use the transferring price to enhance the effectiveness of this approach, so that the risk can be further reduced. Next, When the coup of a host country occurs and it affects the interests of multinational corporations, the multinational corporations may transfer the material and equipment confiscated by the local government to subsidiaries or affiliates at low prices, or acquire goods of other subsidiaries at high prices, which may realize the aim of transferring plenty of funds outside the host country and reduce the impact of political risk on multinational corporations. At last, when facing that some governments in host countries implement the policies of market price control in order to limit and manage the operations of multinational corporations in the local, multinational corporations often use transferring price as a counter measure to avoid the price limit.

\subsection{Adjusting the flow of internal funds to gain competitive advantages}

In order to improve the competitiveness of overseas subsidiaries, the multinational corporations often provide extremely low transferring price in granting their subsidiaries raw materials, components or finished products and so on, so that their subsidiaries can have a price advantage, improve the business reputation, and increase the market competitiveness in the host country in order to beat some opponents and expand the international status of the corporation. In addition, in order to avoid excessive profits to the investors in the host countries or acquisition of local shareholders, or the demand requested by the government in the host country and even the risk of retaliatory behavior, the multinational corporations can also depress the profitability of their subsidiaries, then they can buy goods from the subsidiaries with lower price or sell goods to the subsidiaries with higher price.

\section{The hazard analysis to the abuse of multinational corporation transferring price}

Through transferring price, multinational corporations control the subsidiaries all over the world, make the subsidiaries obey their global strategic objectives and ensure themselves to maximize the profits. However, when multinational corporations abuse transferring price to achieve their purpose, their actions would also bring about adverse effects to the economic development of the host countries. The adverse effects have the following main aspects.

\subsection{Contrary to the principle of tax fairness, serious damage to the tax revenue interests of the host countries}

Multinational corporations misuse transferring price to obtain extra illegal income, which is contrary to the principle of tax fairness, disrupts the fair and orderly running order of international economy, and not conductive to normal development of international trade and investment. In addition, multinational corporations use the 'high-low price' transferring price to transfer the profits of the subsidiaries outside the host countries, which will make the taxable income of multinational corporations in the host countries greatly reduced, and seriously damage the tax revenue interests of the host countries.

\subsection{Deterioration of the international income and payments in the host countries}

The 'high-low price' transferring price of the multinational corporations sharply deteriorates the international income and payments in the host countries. On the one hand, the use of transferring price can increase the overall profit of foreign businessmen thereby drive the foreign businessmen to import goods that can produce domestically, which will cause the host country to increase imported goods. On the other hand, when multinational corporations purchase the same number of produces, services, technology and so on from or sell the same number of products to the related companies abroad, the 'high-low price' of transferring price will cause the host countries to increase imported goods and intangible expenses, and to decrease exported goods, which will deteriorate the international income and payments in the host countries.

\subsection{Undermining the market environment with fair competition}

Sometimes in order to capture the market and suppress competitors, multinational corporations formulate lower 
internal transferring price so that subsidiaries can sell products with a price that is less than a normal price and is even a production cost. Apparently, this action does not do harm to consumers and benefits consumers instead. However, in fact this action is the one that can seriously jeopardize market competition, bring about substantively harm or threat to similar enterprises, and obstruct or threaten the survival and development of competitors.

\subsection{Damaging the image of the host countries when they absorb foreign investment}

Through the 'high-low price' transferring price strategy, the multinational corporations transfer the profit from the host countries and make the book appear low profit or even loss, which creates a false impression that investment in the host countries is profitless. This false impression can affect the enthusiasm of foreign tradesmen who are willing to invest in the host countries, which not only does harm to the reputation of investment environment in the host countries all over the world, but also is harmful to import more foreign funds and advanced technology.

3.5 Dumping in disguise in the host countries market, and doing harm to the related industries in the host countries

When the enterprises avoid tax by the transferring price, they can obtain some unfair competitive advantages because their real tax is lower than normal tax level. Therefore, those honest and law-abiding taxpayers have fallen into a vulnerable competitive position. Some subsidiaries that the multinational corporations invest in the host countries use the transferring price strategy to import a lot of goods from the foreign production base of the parent corporations with the price that is lower than the cost. Then the multinational corporations dump those goods in the market of the host countries, which makes an impact for the similar characteristics enterprises in the host countries. Nowadays, many countries have already made the relevant anti-dumping laws or regulations in order to collect anti-dumpling tax for the dumping goods with low prices.

\section{6 affecting the macro-control in the host countries}

The fiscal policy is an important means for the country to make the macroeconomic control, and the tax system is one important part in it. One the one hand, we can adjust the resources allocation among different industrial sectors by the tax system, and guide resources to flow to the industries that the states encourage. For example, the high-tech industries that the states encourage should use a lower tax rate. On the other hand, tax revenue is an important source for the fiscal revenue of one country and it can also adjust the process of revenue allocation. The multinational corporations use the transferring price to transfer the profit, avoid tax, make the real tax rate lower than the normal tax rate, or even regularly the same with the tax rate used by the industry that the state encourages. Therefore, the actions above reduce the enthusiasm for the resources to flow to the industry encouraged by the state, and make the industry structure adjustment not reach the expected effect. Revenue allocation refers to the allocation between the individual and group, domestic and foreign investment. Obviously, the tax evasion of the multinational corporations makes the revenue flow more to the foreign investment, and also increases the gap of revenue allocation.

\section{Suggestions to consummate management mechanism of transferring price}

According to the harm above, the author proposes the following suggestions.

\subsection{Correctly understanding the necessity of the transferring price management}

It is traditionally considered that control of transferring price may affect the use of foreign capital. However, from the international practice point of view, tax benefits and even tax avoidance through the transferring price is not the only incentive motivation for foreign tradesmen to do multinational investment. The most important factor to attract multinational investment in the host countries is whether there is an extremely superior investment environment in the host countries. If the transferring price legislation consists of the principles that are recognized all over the world just like normal trade principles and these principles have been implemented unifiedly and effectively, then we can make a conclusion that stable and clear legal system consists of a good investment environment in order to attract multinational investment, especially to attract high-tech investment.

\subsection{Improving the tax legislation and strengthening tax intelligence work}

One main purpose of multinational companies using the internal transferring price is tax avoidance. Therefore, the fundamental method of reducing the abuse of transferring price to avoid tax is to improve the tax legislation. At present, the United States is doing the best in this area. Therefore, other countries can partly learn from the successful experience of the United States. The current practice of the United Stated is to make a change to the transferring price from adjustment after the transaction to recognition before the transaction. The reason for this change is that adjustment after the transaction has much disadvantage such as large difficulties in practice that may cause controversy between tax side and tax payment side, a long time to deal with, consuming large 
amounts of manpower and resources and so on. The main method to recognize before the transaction is the advanced pricing method, which means that before the transaction happens, taxpayers inform the tax authorities in relevant countries about the internal transferring price of the related parties and valuation calculation method, and make it as the tax price after confirmed by the tax authorities. Recognition before the transaction overcomes the disadvantages of adjustment after the transaction. Therefore, recognition before the transaction should be the main method to deal with transferring price.

At the same time, we should strengthen tax intelligence work and set up data information network. The host countries should establish an authoritative price information agency. Relevant departments should coordinate with each other, exchange information from each other, and set up perfect price information feedback mechanism which can provide the relevant domestic and foreign price information for national tax authorities and assist the smooth progress of the work of anti-avoidance.

\subsection{Constructing high-quality tax team and ensuring effective enforcement of legislation}

The first one is to set up special agencies to inspect transferring price, and design the work process of inspecting transferring price. This will help inspect the professionalization and scientification of the procedure. The second one is to review the work with international tax experts and professional assets appraisers. New employees should be strictly selected, required to attend training for a certain period, and be employed after passing the examination. When we have difficulties in evaluating the value of intangible assets and advanced technology, we can hire the professional advisory agency to complete. The third one is to train the employees regularly in order to improve the overall quality of reviewers and establish a high level foreign tax team that are familiar with tax law, international trade and multinational enterprises, and have ability to verify the transferring price.

\subsection{Strenthening international cooperation, and controlling transferring price together}

It is an international problem to restrict multinational corporations to use internal transferring price. It is very difficult to prevent the transferring price of multinational corporations thoroughly when we only depend on the law control of one country. Regularizing the multinational corporations as a whole can not be done by only one country, and need the international society regularize and coordinate the activities of the overall multinational corporations. Therefore, the transferring price can be effectively controlled only when countries strengthen the international corporation and take joint action. In addition, it is also an effective way to strengthen information collection work in the international market, set up intelligence information system, exchange intelligence in the international countries and assist mutually, which means that we can exchange the materials about the transferring price of the multinational corporations and assist the opposite side survey, audit and comprehensively review the situation about the multinational corporations in order to provide accurate and timely information materials for resisting the transferring price of multinational corporations.

\section{References}

Cui, Yinghui. \& Zhang, Wei. (2009). Regularizing the Transferring Price of the Enterprises and Promote the Development of Harmonious Society. Productivity Study.

Zhang, Ji. (2007). The Methods and Countermeasures of the Multinational Corporations Implementing the Transferring Price. Economist.

Xue, Na. \& Yang, Bei. (2008). The Strategy of Transferring Price for the Multinational Corporations in the marketing. Age Economic \& Trade.

$\mathrm{Xu}$, Xiaoqing. Study on the effects and Countermeasures for the Transferring Price of Foreign-invested Enterprises. Jiangxi Social Science.

Emerson, Roger. (1997). International Transfer Pricing in Questions of Procedure and Self- assessment. British Tax Review

Michael F Patton. (1998). Canada and U.K. Propose Arm's Length Transfer Pricing Rules. The Tax Adviser

Alexander Vogele. (2001). Transfer Pricing Regulations Derailed by High Court Decision. International Tax Review

Otsuka, Ichira. (1994). Japan and US in Transfer Pricing War. International Tax Review

Hirshleifer J. (1956). On The Economics OF Transfer Pricing. Journal of Business

Wu F. H. and D. Sharp. (1979). An Empirical Study of Transfer Pricing. The Internarional Journal of Accounting. 